\title{
Present trends and future prospects for poplar utilization in Alberta
}

\author{
W.J. Ondro ${ }^{1}$
}

\begin{abstract}
Between 1980 and 1990, poplar (mainly trembling aspen, Populus tremuloides Michx.) harvested on Crown and private lands in Alberta increased from 2.4 to $24.7 \%$ of the total harvest. In 1987-90, three oriented strandboard mills used more than $40 \%$ of the 1.4 million $\mathrm{m}^{3}$ of annual harvest of poplar from Crown and private lands. By the year 2000, the poplar harvest of five pulp and paper mills to be built between 1990 and 2000 is expected to reach about 8.5 million $\mathrm{m}^{3}$. By then, the pulp and paper industry will use about four-fifths of all poplar cut in Alberta.
\end{abstract}

\section{Résumé}

Entre 1980 et 1990 , le peuplier (principalement le peuplier faux-tremble Populus tremuloides Michx.) récolté sur les terres publiques et privées de l'Alberta est passé de 2.4 à $24.7 \%$ de la récolte totale. En 1987-90, trois usines de panneaux à fibre orientée ont utilisé plus de $40 \%$ des 1.4 millions de $\mathrm{m}^{3}$ de la récolte annuelle de peuplier des terres publiques et privées. D'ici l'an 2000, la récolte de peuplier effectuée par les cinq usines de pâtes et papier qui seront construites entre 1990 et 2000 devrait atteindre près de 8.5 millions de $\mathrm{m}^{3}$. A ce moment, l'industrie des pâtes et papier utilisera près des quatre cinquièmes de tout le peuplier récolté en Alberta.

\section{Introduction}

Trembling aspen (Poipulus tremuloides Michx.) is by far the most important poplar in Canada. Together with balsam poplar (Populus balsamifera L.) and black cottonwood (Populus trichocarpa Torr. and Gray), poplar species account for about $11 \%$ of the total Canadian growing stock and over half of all the hardwoods (Zsuffa et al. 1979). Alberta poplar makes up a quarter of the Candian poplar inventory. In Alberta, a third of the total growing stock is poplar and birch (about 830 million $\mathrm{m}^{3}$ ), and four-fifths of this is aspen; yet only $24.7 \%$ of the annual allowable hardwood cut (AAC) of 10.4 million $\mathrm{m}^{3}$ was used in 1990 . This paper discusses historical and present trends, and outlines the future direction for poplar utilization in Alberta.

\section{Past Uses}

Until 1983 only a small fraction of the large deciduous resource in Alberta was used. From 1962 to 1966, about $85800 \mathrm{~m}^{3}$ of poplar logs (mainly aspen) were harvested annually (Jackson 1966). Poplar was used mainly for veneer and plywood (75\%), and the remainder for lumber and fuelwood (Jackson 1966). Balsam poplar veneer and plywood were first manufactured by Northern Plywood Ltd. in Grande Prairie starting in 1953 (Fregren 1980). The company was subsequently taken over by CANFOR. Aspen lumber and studs were produced by several small mills, the largest of which was the North American Stud Company operated in Slave Lake between 1971 and 1975. The pattern of poplar use has gradually changed, however, largely owing to increased aspen utilization for panel products in the early 1980s.

\section{Present Utilization}

A milestone in aspen and poplar utilization in Alberta was the start-up of the aspenite flakeboard mill by the Alberta Aspen Board Ltd. at Slave Lake in 1974-75. After a year of operation the mill closed because of low demand for the

${ }^{1}$ Research Economist, Forestry Canada, Northern Forestry Centre, 5320 122 St., Edmonton, Alberta T6H 3S5. product and problems associated with aspen processing. In 1981 Alberta's first waferboard mill (WB) with an annual capacity of 160 million sq. $\mathrm{ft}$. was started up at the same site by Weldwood Canada Limited. Since then, two new oriented strandboard (OSB) mills have come on stream, and the waferboard mill has since been converted to OSB. Oriented strandboard is marketed and used as a plywood subsitute for sidewall sheathing, roofing, flooring, and other applications. The proportion of OSB used for these purposes has been gradually increasing as OSB has gained wider acceptance. As a result, poplar harvested on Crown and private lands in Alberta increased over tenfold between 1980 and 1990 , from $2.4 \%$ to $24.7 \%$ (Fig. 1) of the total harvest.

Until recently, hardwood (poplar) pulp was produced only in Ontario and Quebec. In 1986, Procter and Gamble at Grande Prairie undertook trial production of aspen bleached kraft pulp (Table 1). Financially viable and readily marketable poplar pulp and paper products that have been identified for Alberta include chemithermomechanical pulps (CTMP), bleached (sulfate) kraft pulps (BKP), market mechanical pulps, newsprint, and printing and writing papers (Woodbridge, Reed and Associates Ltd. 1985). In August 1988, the new Millar Westen combined softwood and aspen CTMP mill at Whitecourt started manufacturing up to 265000 tonnes $(\mathrm{t})$ of bleached flash-dried pulp. This mill alone will increase poplar utilization for pulp from $15.4 \%$ (Table 1) in 1988 to about $30 \%$ in 1989 , which in turn was further increased by Daishowa to $50.9 \%$ in 1990 (Table 1).

The attempts to make solid wood products from poplars has been plagued with a number of problems such as excessive wetness, furry and warping during drying, and stiff competition from relatively abundant and higher value softwood (spruce, pine, and fir) products. Despite the low demand for poplar solid wood products, 118 small sawmills in Alberta produced about 13 million fbm (Table 1) of poplar dimension lumber, timbers, and boards in 1990-91. The low capital and operating costs of these small sawmills allow them to utilize poplar despite relatively low prices for poplar solid wood products. Poplar lumber is used in the construction of houses, garages, and utility buildings. Poplar is also utilized for tongue-and-groove panelling, feature walls, doors 


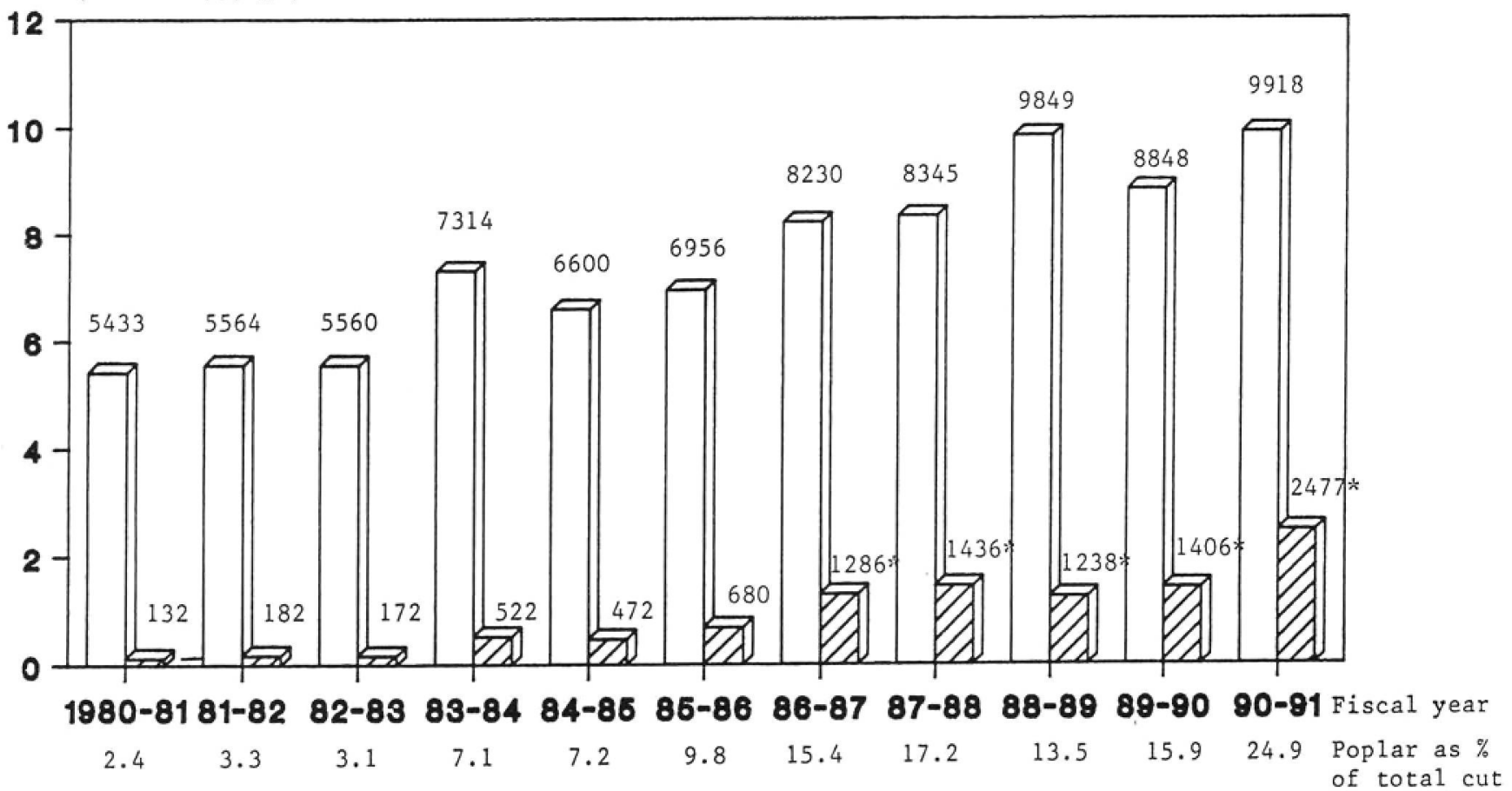

\section{Sof twood and poplar EZT Poplar}

Figure 1. Poplars cut as a percentage of total harvest in Alberta between 1980 and 1990. *It includes volume of poplars cut from private lands. Sources: Alberta Forestry, Lands and Wildlife, Edmonton, Alberta, and telephone survey of poplar-using industries in Alberta by the author, March 1991.

and windows, flooring for houses and barns, and truck and trailer decking. Lumber production can be profitable from these mills, which are located near high-quality poplar stands and close to local lumber markets. A good opportunity exists in secondary manfuacturing of this lumber for pipeline skids, skid racks, dunnage, pallets, furniture, and other products. Two mills in Spruce Gove and Wildwood build aspen daycare furniture, school shelving, and computer tables.

\section{Future Prospects}

Future direction in poplar utilization includes a significant increase in deciduous pulp production by new mills at Peace River, Slave Lake, Athabasca, and Whitecourt and expanded production of existing mills, e.g., Grande Prairie. These mills will utilize large volumes of aspen and balsam poplar by the late 1990s (Table 2). The start-up harvest levels at these facilities are expected to be lower than indicated in Table 2.

The new mills in Alberta will market bleached kraft pulp locally and overseas to Japan and South Korea, which now import almost one-half of their supply from Brazil (CarrolHatch (International) Ltd. 1983). Alberta's poplar pulp and paper mills will be competitive internationally (Jaakko Pöyry International Oy 1983) because of low stumpage and energy costs.

These new forestry developments which utilize aspen and balsam poplar, will substantially increase employment in the forestry sector. About 3200 direct and 6500 direct personyears of employment will be generated when these projects reach their full capacity. The estimated capital cost of these mills is about $\$ 4$ billion.

Even with these new mills coming on stream in the 1990s, some room for expansion exists for the pulp industry in the two remaining timber development areas of High Prairie and High Level - Fort Vermillion and in remanufacturing of primary poplar wood products into high-value secondary products. The furniture mills at Spruce Grove and Wildwood are good examples of this.

\section{Conclusions}

With these expansions, most or all of the poplar AAC (10.4 million $\mathrm{m}^{3}$ ) is expected to be used in Alberta by the year 2000. Several major challenges remain:

(1) expanded profitable use of balsam poplar, which presently is underutilized;

(2) reduction of poplar sawmill residues;

(3) development of off-shore markets for higher-value added secondary poplar-using products such as the Jaegar "I Beam" and the Alberta Research Council's patented process for "Waveboard"; and

(4) development of hybrid poplar short-rotation plantations near the mills to accommodate an increased demand for cheap fibre in the future.

\section{Acknowledgments}

The author wishes to thank the owners and management personnel of all forest industry groups using poplars for providing confidential information on their operation. 
Table 1. Number of poplar-using industries in Alberta and annual production from crown and private lands and employment 1990-1991 ${ }^{1}$

\begin{tabular}{|c|c|c|c|c|c|}
\hline \multirow[b]{2}{*}{ Industry } & \multirow[b]{2}{*}{ No. plants } & \multicolumn{2}{|c|}{ Log input ${ }^{2}$} & \multirow[b]{2}{*}{ Production } & \multirow{2}{*}{$\begin{array}{l}\text { Employment in } \\
\text { mills } \\
\text { and woodlands } \\
\text { (person-years) }\end{array}$} \\
\hline & & $\mathrm{m}^{3}$ & $\%$ & & \\
\hline OSB mills ${ }^{3}$ & 3 & $1,093,100$ & 43.7 & 670 MM sq. $\mathrm{ft}^{4}(3 / 8$-in. $)$ & 789 \\
\hline \multirow[t]{3}{*}{ Pulp and paper mills (1990 use) } & $1^{5}$ & 91,632 & 3.7 & $24000 \mathrm{t}$ aspen & 70 \\
\hline & 1 & 840000 & 33.9 & $\begin{array}{l}182,609 \mathrm{t} \text { aspen bleached kraft } \\
\text { pulp }\end{array}$ & 600 \\
\hline & $1^{7}$ & 330,000 & 13.3 & $\begin{array}{l}100,000 t \text { aspen bleached flash- } \\
\text { dried pulp }\end{array}$ & 225 \\
\hline $\begin{array}{l}\text { Sawmill-planing mill complexes }{ }^{9} \\
\text { producing } 100 \mathrm{M} \text { to } 1 \mathrm{MM} \mathrm{fbm}\end{array}$ & 22 & 50,675 & 2.0 & $11.9 \mathrm{MM} \mathrm{fbm}$ & 125 \\
\hline $\begin{array}{l}\text { Sawmill-planing mill complexes }{ }^{9} \\
\text { producing less than } 100 \mathrm{M} \mathrm{fbm}\end{array}$ & 96 & 7,481 & 0.3 & $1.7 \mathrm{Mm} \mathrm{fbm}$ & 61 \\
\hline Firewood producers & Not available & 41,500 & 1.7 & Not applicable & Not available \\
\hline Pallet mills ${ }^{10}$ & 2 & 31,300 & 1.3 & 208600 pallets & 53 \\
\hline Container mills & 1 & Not applicable & 0.0 & Not available & 3 \\
\hline Furniture mills & 2 & 430 & 0.0 & $\begin{array}{l}400 \text { computer tables } \\
400 \text { shelving units } \\
200 \text { pieces day-care furniture }\end{array}$ & 43 \\
\hline Cattle feed pelleting mill & 1 & 900 & 0.0 & Aspen cattle pellets & 12 \\
\hline Total & 129 & $2,477,017$ & $99.9^{11}$ & & 1,981 \\
\hline \multicolumn{6}{|c|}{$\begin{array}{l}\text { 'Sources: Alberta Forestry, Lands and Wildlife, Edmonton, Alberta, and telephone survey of poplar-using industries in Alberta by the author, } 1991 \\
{ }^{2} \text { Includes poplar logs harvested from Alberta's Crown and private lands and logs purchased outside the province. }\end{array}$} \\
\hline
\end{tabular}

Table 2. New and proposed poplar (aspen) pulp and paper mills in Alberta to March 1991 (Alberta Forestry, Lands and Wildlife).

\begin{tabular}{|c|c|c|c|c|c|c|c|c|c|c|}
\hline \multirow[b]{2}{*}{ Company } & \multirow[b]{2}{*}{ Location } & \multirow[b]{2}{*}{ Type of pulp ${ }^{1}$} & \multirow[b]{2}{*}{ Date of opening } & \multicolumn{2}{|c|}{$\begin{array}{c}\text { Species utilization } \\
\left(\left(000 \mathrm{~m}^{3}\right)\right.\end{array}$} & \multicolumn{2}{|c|}{$\begin{array}{l}\text { Annual pulp } \\
\text { output }{ }^{2} \\
(' 000 t)\end{array}$} & \multirow{2}{*}{$\begin{array}{c}\text { Capital cost } \\
\text { (million \$) }\end{array}$} & \multicolumn{2}{|c|}{$\begin{array}{c}\text { Employment } \\
\text { (person-years) }\end{array}$} \\
\hline & & & & Aspen & Softwood & Aspen & Softwood & & Direct & Indirect \\
\hline \multicolumn{11}{|l|}{ In operation: } \\
\hline $\begin{array}{l}\text { Millar Western } \\
\text { Industries Ltd. }\end{array}$ & Whitecourt & $\begin{array}{l}\text { CTMP } \\
\text { producing } \\
\text { BFDP }\end{array}$ & August 1988 & 315 & 298 & 105 & 105 & 205 & 225 & 450 \\
\hline $\begin{array}{l}\text { Alberta Newsprint } \\
\text { Company Ltd. }\end{array}$ & Whitecourt & $\begin{array}{l}\text { CTMP } \\
\text { newsprint }\end{array}$ & August 1990 & 132 & 500 & 44 & 176 & 360 & 375 & 750 \\
\hline $\begin{array}{l}\text { Daishowa Canada } \\
\text { Co. Ltd. }\end{array}$ & Peace River & BKP & September 1990 & 1,194 & 630 & $630^{3}$ & 110 & 500 & 630 & 1.260 \\
\hline $\begin{array}{l}\text { Alberta Energy Co. } \\
\text { Ltd. }\end{array}$ & Slave Lake & CTMP & January 1991 & 264 & 53 & 88 & 22 & 168 & 122 & 245 \\
\hline \multicolumn{11}{|l|}{ In construction: } \\
\hline $\begin{array}{l}\text { Procter and Gamble } \\
\text { Cellulose Ltd. }\end{array}$ & $\begin{array}{l}\text { Grande } \\
\text { Prairie }\end{array}$ & BKP & January 1992 & 690 & 690 & 150 & 150 & 400 & 600 & 1,200 \\
\hline $\begin{array}{l}\text { Alberta-Pacific Forest } \\
\text { Industries Ltd. }\end{array}$ & Athabasca & BKP & October 1993 & 1,800 & 360 & $390^{4}$ & 106 & 1,300 & 1,300 & 2,600 \\
\hline Total & & & & 4,395 & 2,531 & 1,407 & 669 & 2,933 & 3,252 & 6,505 \\
\hline
\end{tabular}

${ }^{1}$ DFDP $=$ bleached flash-dried pulp; BKP = bleached draft pulp; CTMP = chemithermomechemical pulp.

${ }^{2}$ Separate aspen and softwood pulp production.

${ }^{3}$ Based on average recovery of 1 tonne of BKP from $5.19 \mathrm{~m}^{3}$ of aspen and $5.73 \mathrm{~m}^{3}$ of softwood.

${ }^{4}$ Also utilizing balsam poplar. 
Appreciation is extended to C.A. Dermott, J.A. Brennan, J.B. Scheffer, D.A. Price, and T. Szabo, all of Alberta Forestry, Lands and Wildlife, for providing information on poplar harvest and critical reviews of the manuscript.

\section{References}

Carroll-Hatch (International Ltd. 1983. Market assessment for poplar products. Volumes 1, 2, and 3. Report prepared for governments of Canada, Alberta, and British Columbia.

Fregren, D.H. 1980. The hardwood future in Alberta. Pages 145-147 in Utilization of Western Canadian Hardwoods. Forintek Canada Corp., Spec. Publ. No. SP-2.
Jaakko Pöyry International Oy. 1983. Competitiveness of Alberta vs. the U.S. southeast forest industry. Report prepared for Alberta Department of Economic Development and Alberta Department of Natural Resources.

Jackson, C. 1966. Poplar utilization in the province of Alberta. Proceedings of an industrial wood products seminar, Edmonton, Alberta, Nov. 8 and 9, 1966.

Woodbridge, Reed and Associates Ltd. 1985. Utilization of hardwoods in Northern Alberta. Report prepared for the Northern Alberta Development Council, Edmonton, Alberta.

Zsuffa, L., D. Boufford and M.A. Legatt. 1979. Poplar biomass production and utilization. Environ. Can., Can. For. Serv., Petawawa Natl. For. Inst., Chalk River, Ontario. ENFOR project P-139.

\section{CIF/IFC Corporate Sustaining Members}
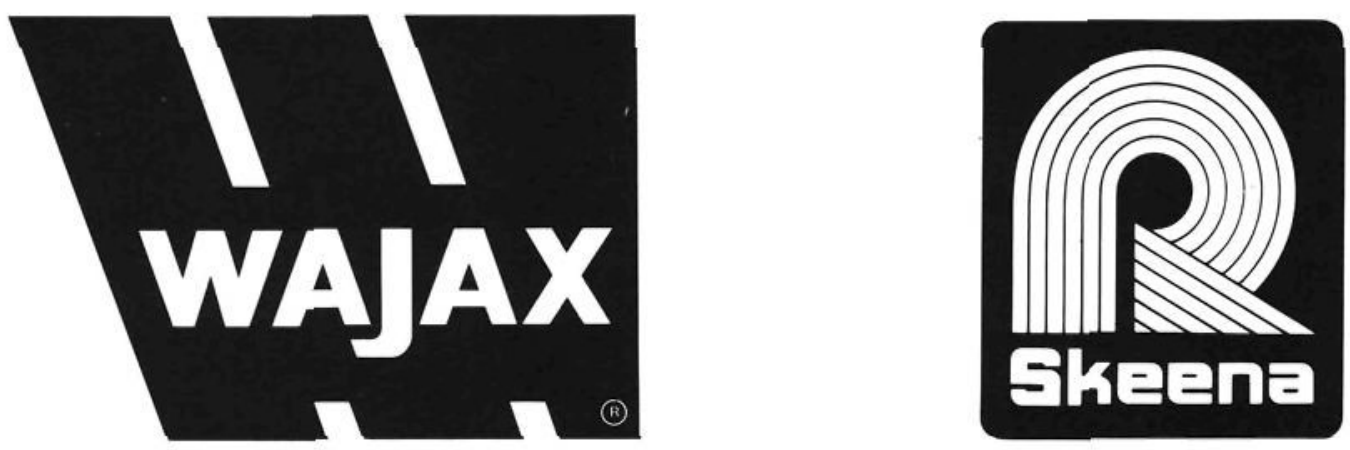

\section{équipements denis inc.}

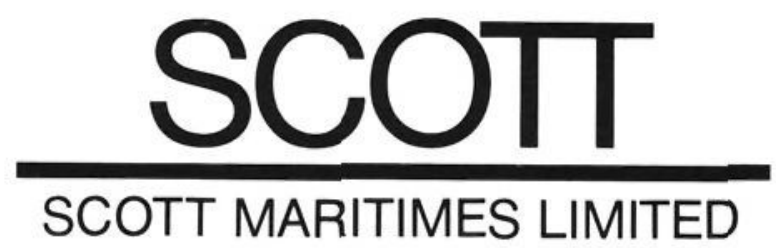

Tिmbec

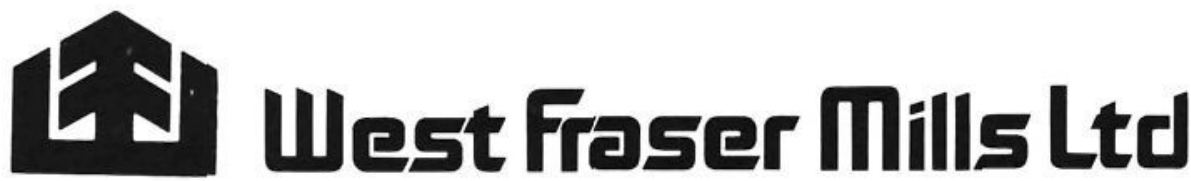

